\title{
Financing Ecological Environment, Financing Capacity and R\&D Investment: An Empirical Study on Listed Companies of New Material Industry in China
}

\author{
Wen Xiong $^{1} \&$ Chengxuan Geng ${ }^{1}$ \\ ${ }^{1}$ College of Economics and Management, Nanjing University of Aeronautics and Astronautics, Nanjing, China \\ Correspondence: Wen Xiong, College of Economics and Management, Nanjing University of Aeronautics and \\ Astronautics, Nanjing 211106, China. Tel: 1-515-069-8502. E-mail: 1390504533@qq.com
}

Received: August 19, 2017

Accepted: September 9, $2017 \quad$ Online Published: September 25, 2017

doi:10.5539/ijef.v9n11p10

URL: https://doi.org/10.5539/ijef.v9n11p10

\begin{abstract}
Introducing the concept of financing ecology into the research of new material enterprises' R\&D investment, and taking 203 Chinese listed companies of new material industry from 2010 to 2015 as the research objects, this paper explores the relationship between financing ecological environment, new material enterprises' financing ability and R\&D investment. The study shows that: Financing ecological environment has significant influence on new material enterprises' R\&D investment; Specifically, two sub dimensions of economics and finance have positive effects, while the sub dimension of system and honesty has negative effects; The promotion of financing capacity helps new material enterprises to increase R\&D investment; Financing capability plays a positive intermediary role between financing ecological environment and R\&D investment. Accordingly, new material enterprises should promote adaptive coevolution between financing ability, R\&D funds allocation and financing ecology, and fully use the support of policy system.
\end{abstract}

Keywords: financing ecological environment, financing capacity, R\&D investment, new material enterprises, TOPSIS

\section{Introduction}

Since China's economy steps into the "new normal" phase, new material industry has become an important driving force for the optimization of industrial structure and sustainable economic development. In 2010, the State Council included new materials into strategic and emerging industries, and then put it in the key development areas of "China Made 2025". "13th Five-Year" is also committed to innovation and development of new materials. Besides the Ministry of industry and information, the NDRC, the Ministry of science and technology and other relevant ministries and commissions have also promulgated guidelines, all of which mentioned the urgency of new material R\&D. Relying on the support of policies, China's new material enterprises grow rapidly, showing the trend of industrial agglomeration. The scale of new material industry increased from 650 billion yuan in 2010 to 1900 billion yuan in 2015 . What cannot be ignored is that, the technical level of new materials is still in the initial stage of growth in China. A universal phenomenon in the field of new material enterprises is that overcapacity of low-end products and high-end products relying on imports, which is an urgency for enterprises to make changes to enhance their capability of technological innovation. R\&D projects of new material enterprises have characteristics of large investment, long investment cycle, slow realization of income and strong uncertainty, making the continuous supply and efficient allocation of fund become important factors.

However, the current studies of China's new material industry are mainly about macro analysis from the perspectives of development process, technological innovation and industrial clusters, while researches on enterprise R\&D investment are mainly about internal factors, which shows these studies lack the consideration for the complex living environment of micro enterprises. Therefore, extending the research vision and introducing the idea of ecosystem, this paper integrates financing ecological environment, new material enterprises' financing ability and R\&D investment into a unified analysis framework. The purpose of this study is to analyze the relationship between financing ecological environment and new material enterprises' $R \& D$ investment, and to explore the mediating effect of financing ability. In this way, we can provide effective theoretical interpretation and practical inspiration for new material enterprises' R\&D fund allocation. 


\section{Literature Review and Research Hypothesis}

\subsection{Financing Ecological Environment and Enterprises' $R \& D$ Investment}

Due to the imbalance of regional economic development, the underdevelopment of capital market, the imperfect development of banking industry, the imperfection of institutional environment and the lack of social trust, new material enterprises are struggling in trouble, and their willingness of $R \& D$ investment is weakening, which is not conducive to the transformation and upgrade of new material industry.

$\mathrm{Lu}$ and Zheng (2007) pointed out that the coordinated development of regional economy will promote the rational allocation of innovation resources, and help enterprises to carry out product technology research. Zong and Gao (2017) indicated that economic factors, such as market openness, human capital, FDI and economic structure, have significant positive impacts on R\&D investment in east china. Obviously, economic development can promote enterprises' R\&D investment, whlie some other scholars discuss it from a financial point of view. Pasi(2008) explored the impact of the national financial system on corporate R\&D investment, and found that bank capital is more conducive to R\&D investment than equity market capital. Wang (2016) found that financial development can ease the financing constraints of R\&D investment of China's enterprises listed on GEM (the Growth Enterprise Market), and thus promote R\&D investment, and banks play a more significant role than the stock market. Some scholars change their research angle. Chen et al. (2012) fully discussed the impact of regional economic, culture, technological progress, government intervention, legal system and property protection on small and medium-sized enterprises' R\&D investment, the result of which shows that the positive environment plays a regulatory role. Marianna et al. (2016) found that under the R\&D tax credit system, the impact of moderate levels of government subsidies on the R\&D expenditure of French enterprises is more significant. Oliviero (2017) investigated the effect of government support on R\&D expenditure based on a sample of manufacturing firms across seven European countries, and the result shows that public grants have a positive effect on firms' $R \& D$, implying that recipient firms spend more than they would have without public aid.

$R \& D$ projects of new material enterprises rely on sustained and solid financial support. What's more, the influence of external financing environment on the supply ability of $R \& D$ funds is obvious. Enterprises make financing activities for the needs of R\&D investment, in which process they interact with the factors of financing ecological environment. This can help push forward the information transfer, resource allocation, capital flow, risk control and profit distribution between these factors and enterprises, which can form the financing value chain, and then the financing value network, and finally the unique financing ecology. The good financing ecological environment can enhance the effectiveness of R\&D funds allocation, and stimulate independent innovation of enterprises. Based on the above analysis, hypothesis 1 has been proposed as follows:

H1: The improvement of financing ecological environment has positive effects on $R \& D$ investment of new material enterprises.

\subsection{Enterprises' Financing Capacity and $R \& D$ Investment}

Sustained and stable source of funds is the key point to new material enterprises' R\&D investment. However, currently, $R \& D$ investment relies on the support of internal funds. And the sensitivity of investment cash flow is widespread. Once enterprises' operating performance decline, it will affect R\&D investment intensity. Scholars have analyzed the impact on R\&D investment from the perspective of financing constraints, financing structure, financing methods and so on.

James et al. (2012) suggested that enterprises should flexibly use stock to improve their financing capacity of R\&D activities. Liu (2014) studied the influence of industry type, financing channels and ownership forms on the financing constraints of R\&D. Subash et al. (2015) examined the extent to which financing constraints affect the R\&D investment of Indian manufacturing enterprises, which showed that newly established companies have higher cash flow sensitivity. Wang et al. (2016) studied the relationships among financing sources, R\&D investment and enterprise risk. They found that the relationship between endogenous financing rate and R\&D investment is significantly positive. Zheng et al. (2017) found that enterprises' financing capacity is positively related with $R \& D$ investment.

On account of the above, new material enterprises' R\&D investment depends on the sufficient supply of funds, that is, the effective support of enterprise financing and allocation. And hypothesis 2 has been proposed as follows:

$\mathrm{H} 2$ : The enhancement of financing capability has positive effects on $R \& D$ investment of new material enterprises. 


\subsection{Financing Ecological Environment, Enterprises' Financing Capacity and $R \& D$ Investment}

The financing ability of enterprises is closely related to the factors of financing ecological environment, such as economy, finance, legal system and honesty. Relying on the substantial economic foundation, enterprises can improve the quality of operation and consolidate the stability of capital flow. While the development of financial factor can reduce the asymmetry of market information and improve the efficiency of capital allocation, in which way enterprises can reduce their financing costs. And system and honesty can create an orderly social environment for rule of law and credit, and reduce the risk of investment and financing.

Song et al. (2015) indicated that firms with political connections will face less financing constraints. Wei et al. (2012) found that the synergy between financial deepening and audit supervision will increase the market pricing of debt financing and improve the efficiency of capital allocation. Fernanda et al. (2015) considered that improving the financial system can enrich financing channels for enterprises. Ali et al. (2017) thought that policy is an important factor of financial intermediation costs, which ultimately can affect enterprises' external financing channels.

The improvement of the financing ecological environment will not only enhance the financing capacity of enterprises, but also stimulate the investment intentions of R\&D. Zhai et al. (2013) mentioned that the development of financial intermediation and stock market can help enterprises to increase financing opportunities, disperse financing risks, and indirectly stimulate R\&D investment. Hiroyuki et al. (2014) examined the impact of the R\&D tax credits on corporate R\&D spending, which indicats that the effect of tax credit is significantly larger for firms with relatively large outstanding debts. Dai (2015) found that the level of regional economic development determines the size of the local financing, and then affect the amount of enterprises' R\&D funds. Yu et al. (2016) studied the R\&D investment of China's renewable energy industry, and found that government subsidies are important sources of R\&D funding, while ownership of enterprises plays a moderating role in the relationship between government subsidies and firm's $R \& D$ activities.

The above studies show that different regional financing ecological environment provides choices and constraints for financing behavior and R\&D investment activities of new material enterprises. In order to adapt to the changes of these financing ecological factors, enterprises shall make corresponding management adjustments to optimize their financing structure. The financing ecological environment, new material enterprises' $R \& D$ behavior and financing ability, the three have complex internal relations, and carry on dynamic coupling, so the hypothesis 3 has been proposed as follows:

H3: Financing capability plays the intermediary role between financing ecological environment and R\&D investment, and there is a conduction relationship between the three.

\section{Study Design}

\subsection{Selection and Measurement of Variables}

\subsubsection{Financing Ecological Environment}

As the survival space of enterprise financing, the elements of financing ecological environment are varied, involving regional economy, financial market, financial intermediary service, legal system, government administration, social honesty and so on, all of which coordinate and interact with each other. This paper selects the key environmental factors that play a leading role in financing ecology to measure the financing ecological environment (marked as E). The three major factors are economic development (marked as E1), financial development (marked as E2) and system and honesty (marked as E3). The following is the detailed description of the multi-level indicator system.

\section{(1) Economic development}

Economic development can directly reflect the capital flow condition of the real economy. Economic decline can negatively affect the operation of enterprises, resulting in a decrease in profits, increasing the possibility of their failure to pay debts on time, blocking the funds financing, and eventually causing a series of negative impacts on investment and financing. Accordingly, economic development is the fundamental support of regional financing ecological environment, and its quality decides regional enterprises' financing level. This paper measures the level of regional economic development from three aspects, economic sophistication, economic structure and infrastructure, individually. Specifically, economic sophistication reflects the accumulation of economic development, which can balance the adverse effects of non-performing assets. And economic structure reflects the distribution of economic resources among industries. While the infrastructure situation reflects the basic conditions of economic operation, and its completeness affects the stability of the region. The description of indicators is shown in Table 1 below. 


\section{(2) Financial development}

The development of financial elements can promote the information symmetry of capital market, and increase the conversion rate of investment and capital liquidity, thus finally can expand the channels of enterprises' investment and financing, and reduce their transaction cost. Hence the level of financial development determines financing efficiency of regional enterprises. This paper judges the level of regional financial development from three aspects, financial efficiency, financial supervision and financial scale. To be specific, financial efficiency reflects the efficiency of the allocation of financial resources. Financial supervision reflects the government's efforts to regulate the financial market. The financial scale reflects the size of assets accumulated by various financial activities.

The selection of indicators in Table 1 are referred to the studies of Wang et al. (2011), Li (2014), Huang (2015) and Zheng et al. (2015).

Table 1. Definition of indicators for economic development and financial development

\begin{tabular}{|c|c|c|}
\hline Sub dimensions & Sub indicators & Indicator description \\
\hline \multirow{9}{*}{$\begin{array}{l}\text { Economic } \\
\text { development } \\
\text { (E1) }\end{array}$} & \multirow{2}{*}{$\begin{array}{c}\text { Economic } \\
\text { sophistication }\end{array}$} & Provincial GDP growth: GDP(end of this year) / GDP(end of last year)-1 \\
\hline & & Consumption level of residents: the average consumption expenditure of resident population \\
\hline & \multirow{3}{*}{$\begin{array}{l}\text { Economic } \\
\text { structure }\end{array}$} & Third industry share: third industry added value / provincial GDP \\
\hline & & Financial industry share: financial industry added value / provincial GDP \\
\hline & & Realty industry share: realty industry added value / provincial GDP \\
\hline & \multirow{4}{*}{ Infrastructure } & Traffic: regional road density $\left(\mathrm{km} / \mathrm{km}^{2}\right)$ \\
\hline & & Telecommunication: per capita volume of Posts and Telecommunications (yuan / person) \\
\hline & & Medical treatment: number of beds ten thousand people in medical institutions \\
\hline & & Education: the number of teachers per ten thousand persons \\
\hline \multirow{6}{*}{$\begin{array}{c}\text { Financial } \\
\text { development } \\
\text { (E2) }\end{array}$} & \multirow{2}{*}{$\begin{array}{l}\text { Financial } \\
\text { efficiency }\end{array}$} & Loan to deposit ratio of financial institutions: Loans / deposits by provincial financial institutions \\
\hline & & Private funding support: provincial small loans / number of microfinance institutions \\
\hline & $\begin{array}{c}\text { Financial } \\
\text { supervision }\end{array}$ & $\begin{array}{l}\text { Government financial supervision: provincial financial regulatory expenditure / provincial } \\
\text { government general budget expenditure }\end{array}$ \\
\hline & \multirow{3}{*}{ Financial scale } & $\begin{array}{l}\text { Deposits and loans of financial institutions: total provincial deposits and loans of financial } \\
\text { institutions / provincial GDP }\end{array}$ \\
\hline & & Securities markets: provincial total market value shares / provincial GDP \\
\hline & & Insurance industry: provincial premium income / provincial GDP \\
\hline
\end{tabular}

Note. The indicator data of economic development and financial development are obtained from the China's Statistics Yearbook, China's Financial Statistics Yearbook and the financial statistics report issued by the China's People Bank. The economic and financial indicators are all positive.

The Technique for Order of Preference by Similarity to Ideal Solution (TOPSIS) is used to measure the multi-level indicators of economic development and financial development. TOPSIS is a multi-criteria decision analysis method, which was firstly put forward by C. L. Hwang and K. Yoon, and applied to the evaluation of the limited projects of system engineering. The method determines the alternatives' order of the pros and cons by calculating the distance between the alternatives and the positive and negative ideal values.

The processing steps of TOPSIS are as follows:

Step 1: Create an evaluation matrix consisting of $m$ alternatives and $n$ criteria, with the intersection of each alternative and criteria given as $x_{i j}$, and set up the original data matrix $\left(x_{i j}\right)_{m \times n}, i=1,2, \ldots, m ; j=1,2, \ldots, n$. Step 2: Normalize $\left(x_{i j}\right)_{m \times n}$ to form the new matrix $\left(y_{i j}\right)_{m \times n}$.

The positive indicator processing method is $y_{i j}=\frac{x_{i j}-x_{\min (j)}}{x_{\max (j)}-x_{\min (j)}}$, while the negative indicator processing method is $y_{i j}=\frac{x_{\max (j)}-x_{i j}}{x_{\max (j)}-x_{\min (j)}}$.

Step 3: Calculate the criteria weight. Calculate the average value $\overline{y_{j}}=\frac{1}{m} \sum_{i=1}^{m} y_{i j}$, and the standard deviation of each indicator sequence $S_{j}=\sqrt{\frac{1}{m-1} \sum_{i=1}^{m}\left(y_{i j}-\bar{y}_{j}^{-}\right)^{2}}$. Then determine the coefficient of difference of each 
indicator sequence $V_{j}=\frac{s_{j}}{\left|\overline{y_{j}}\right|}$, and get the weight of the criteria $w_{j}=\frac{V_{j}}{\sum_{j=1}^{n} v_{j}}$.

Step 4: Calculate the weighted normalized decision matrix: $\left(a_{i j}\right)_{m \times n}=\left(y_{i j}\right)_{m \times n} \cdot w$, in which $\mathrm{w}=\begin{array}{ccc}w_{1} & \ldots & 0 \\ \vdots & \ddots & \vdots \\ 0 & \ldots & w_{n}\end{array}$

Step 5: Determine the worst alternative and the best alternative. The $\mathrm{j}$ attribute value of the worst alternative is $a_{j}^{-}=\left\{\min a_{i j} \mid i=1,2, \ldots, m\right\}$, while the $\mathrm{j}$ attribute value of the best alternative is $a_{j}^{+}=\left\{\max a_{i j} \mid i=1,2, \ldots, m\right\}$.

Step 6: Calculate the distance from $a_{i j}$ to the best and worst alternatives, which are $d_{i}^{+}=\sqrt{\sum_{j=1}^{n}\left(a_{i j}-a_{j}{ }^{+}\right)^{2}}$, $d_{i}^{-}=\sqrt{\sum_{j=1}^{n}\left(a_{i j}-a_{j}^{-}\right)^{2}}$, respectively.

Step 7: Calculate the distance of each alternative to the worst condition: $C_{i}=\frac{d_{i}{ }^{-}}{d_{i}{ }^{+}+d_{i}{ }^{+}}$.

The greater the value of $C_{i}$, the better the project, which means the higher level of economic development and financial development in the region, and vice versa.

(3) System and honesty

Good system and honesty can guarantee the stability of financing ecology, and prevent credit fraud and debt evasion. However, the institutional environment in different regions is uneven, so whether the administrative management is standardized has been profoundly affecting the behavior of economic individuals. As the soft environment of financing ecology, honesty culture gradually forms credit norms in long-term economic activities. But it is difficult to find a set of criteria, which is accurate, objective and reasonable, to judge the situation of system and honesty.

"The evaluation of China's regional financial environment" is a research topic carried out by the Institute of finance of the Chinese Academy of Social Sciences since 2006. To date, the Institute has published four editions (2006-2007, 2008-2009, 2009-2010 and 2013-2014), among which, the Institute carried out a full range of questionnaires about the system and integrity level through investigating the sample enterprises and regional financial institution's judicial, government integrity, claims maintenance, social credit and other aspects. The content of the books is rich, complete and persuasive.

Therefore, the data of system and honesty in 2010, 2013 and 2014 are referred from this research. And this paper combines the GM $(1,1)$ model of the Grey System Theory to predict the absent data of system and honesty in 2011, 2012 and 2015 (see Table 2 below).

Table 2. The level of system and honesty of 30 provinces in China from 2010 to 2015

\begin{tabular}{ccccccccc}
\hline Provinces & 2010 & $\begin{array}{c}2011 \\
\text { (forecast) }\end{array}$ & $\begin{array}{c}2012 \\
\text { (forecast) }\end{array}$ & 2013 & 2014 & $\begin{array}{c}2015 \\
\text { (forecast) }\end{array}$ & $\begin{array}{c}\text { Adopted forecasting } \\
\text { model }\end{array}$ & $\begin{array}{c}\text { Average } \\
\text { relative error }\end{array}$ \\
\hline Beijing & 0.729 & 0.694 & 0.675 & 0.654 & 0.641 & 0.624 & EGM & $1.65 \%$ \\
Tianjin & 0.592 & 0.678 & 0.695 & 0.602 & 0.613 & 0.587 & EGM & $5.06 \%$ \\
Hebei & 0.406 & 0.431 & 0.409 & 0.386 & 0.417 & 0.383 & EGM & $3.35 \%$ \\
Shanxi & 0.298 & 0.325 & 0.349 & 0.378 & 0.394 & 0.421 & EGM & $8.02 \%$ \\
Inner Mongolia & 0.389 & 0.417 & 0.361 & 0.384 & 0.359 & 0.408 & EGM & $9.76 \%$ \\
Liaoning & 0.415 & 0.469 & 0.438 & 0.422 & 0.449 & 0.421 & EGM & $4.36 \%$ \\
Jilin & 0.421 & 0.413 & 0.402 & 0.396 & 0.435 & 0.402 & EGM & $6.79 \%$ \\
Heilongjiang & 0.389 & 0.364 & 0.347 & 0.325 & 0.344 & 0.379 & EGM & $5.64 \%$ \\
Shanghai & 0.731 & 0.851 & 0.837 & 0.892 & 0.813 & 0.776 & EGM & $5.04 \%$ \\
Jiangsu & 0.647 & 0.613 & 0.625 & 0.572 & 0.608 & 0.567 & EGM & $1.76 \%$ \\
Zhejiang & 0.760 & 0.692 & 0.654 & 0.590 & 0.585 & 0.553 & EGM & $5.86 \%$ \\
Anhui & 0.521 & 0.501 & 0.537 & 0.495 & 0.523 & 0.516 & EGM & $5.97 \%$ \\
Fujian & 0.604 & 0.589 & 0.546 & 0.541 & 0.562 & 0.526 & EGM & $2.86 \%$ \\
\hline
\end{tabular}




\begin{tabular}{cllllllll}
\hline Jiangxi & 0.459 & 0.398 & 0.335 & 0.387 & 0.356 & 0.402 & EGM & $6.30 \%$ \\
Shandong & 0.612 & 0.595 & 0.563 & 0.515 & 0.526 & 0.503 & EGM & $3.30 \%$ \\
Henan & 0.378 & 0.426 & 0.365 & 0.409 & 0.428 & 0.383 & EGM & $6.91 \%$ \\
Hubei & 0.443 & 0.429 & 0.378 & 0.409 & 0.436 & 0.385 & EGM & $8.44 \%$ \\
Hunan & 0.485 & 0.467 & 0.421 & 0.440 & 0.464 & 0.429 & EGM & $7.02 \%$ \\
Guangdong & 0.557 & 0.573 & 0.579 & 0.558 & 0.590 & 0.576 & EGM & $2.97 \%$ \\
Guangxi & 0.409 & 0.427 & 0.386 & 0.424 & 0.375 & 0.411 & EGM & $5.79 \%$ \\
Hainan & 0.398 & 0.425 & 0.401 & 0.417 & 0.393 & 0.377 & EGM & $4.99 \%$ \\
Chongqing & 0.622 & 0.643 & 0.627 & 0.568 & 0.620 & 0.594 & EGM & $5.23 \%$ \\
Sichuan & 0.463 & 0.529 & 0.446 & 0.407 & 0.429 & 0.395 & ODGM & $6.34 \%$ \\
Guizhou & 0.225 & 0.268 & 0.296 & 0.350 & 0.388 & 0.359 & ODGM & $6.06 \%$ \\
Yunnan & 0.471 & 0.426 & 0.383 & 0.367 & 0.302 & 0.387 & ODGM & $7.45 \%$ \\
Shaanxi & 0.326 & 0.374 & 0.417 & 0.384 & 0.370 & 0.404 & EGM & $6.74 \%$ \\
Gansu & 0.269 & 0.247 & 0.302 & 0.367 & 0.405 & 0.353 & DGM & $8.53 \%$ \\
Qinghai & 0.268 & 0.303 & 0.341 & 0.364 & 0.396 & 0.379 & EGM & $6.83 \%$ \\
Ningxia & 0.371 & 0.336 & 0.274 & 0.232 & 0.273 & 0.308 & DGM & $8.91 \%$ \\
Xinjiang & 0.312 & 0.304 & 0.335 & 0.321 & 0.339 & 0.362 & EGM & $7.22 \%$ \\
\hline
\end{tabular}

Note. The GM $(1,1)$ model of the Grey System Theory has been used to forecast the level of system and honesty of 30 provinces in 2011, 2012 and 2015, by comparing the four average relative error values $\Delta$ of the four basic GM (1,1) models (EGM, ODGM, EDGM and DGM) results, and selecting the predicted results whose $\Delta$ are the smallest.

\subsubsection{Financing Capacity}

Financing capability (marked as RZ) is measured from four dimensions: financing guarantee, financing structure, financing cost and financing risk. Concretely, cash holdings are the guarantee of debt repayment, and the more cash holdings, the easier it is for new material enterprises to obtain external financing. The financing structure reflects the composition of the enterprise's financing from different channels. The financing cost is the cost of external funds, mainly interest payments on short-term liabilities, long-term liabilities and dividends paid for business owners. Financing risk refers to the extent to which the enterprise's financing behavior affects the income. And financial leverage can well explain the impact of debt activities on the profit after tax, which is suitable to measure the financing risk, accordingly. The TOPSIS method is also used to measure the multi-level indicator of enterprises' financing capacity. The indicators of four dimensions are in the Table 3 below, which are referred to the theses of $\mathrm{Li} \mathrm{(2015)}$ and Tan (2016).

\subsubsection{R\&D Investment}

$\mathrm{R} \& \mathrm{D}$ investment (marked as $\mathrm{RD}$ ) comes from $\mathrm{R} \& \mathrm{D}$ expenses of enterprises, which indicates how much an enterprise is willing to spend from business income for technical research.

\subsubsection{Controlled Variables}

The R\&D investment of new material enterprises is not only affected by the financing ecological environment and their financing capacity, but also affected by the scale, potential and stability of enterprises. Therefore, firm size (marked as Size), growth capability(marked as Growth) and ownership concentration (marked as Equity) are used as control variables.

Table 3. Definition of indicators for financing capability, R\&D investment and controlled variables

\begin{tabular}{|c|c|c|}
\hline & Indicators & Indicator description \\
\hline \multirow{4}{*}{$\begin{array}{l}\text { Financing } \\
\text { capability }\end{array}$} & Financing guarantee & (Cash on hand + bank deposit + other monetary capital) /assets \\
\hline & Financing structure & (Payables + short-term borrowings + long-term borrowings) / assets \\
\hline & Financing cost & $\begin{array}{l}\text { Cash paid for dividends, profits, or interest (/ short term borrowings + long term } \\
\text { borrowings + owner's equity) }\end{array}$ \\
\hline & Financing risk & Financial leverage \\
\hline \multicolumn{2}{|c|}{ R\&D investment } & R\&D expenses / revenue \\
\hline \multirow{3}{*}{$\begin{array}{c}\text { Control } \\
\text { variables }\end{array}$} & Firm size & Ln(assets) \\
\hline & Growth capability & Revenue growth rate \\
\hline & Ownership concentration & The sum of the shares of the top ten shareholders \\
\hline
\end{tabular}

Note. Enterprises' financial data are obtained from financial statements of listed companies in the CSMAR Database. The indicators of financing guarantee and financing structure are positive, while the indicators of financing cost and financing risk are negative. 


\subsection{Model Building}

\subsubsection{Test Hypothesis H1}

Build model (1) to test the relationship of financing ecological environment and enterprises' R\&D investment:

$$
R D_{i, t}=\beta_{1} E_{i, t}+\beta_{2} \text { LnAsset }_{i, t}+\beta_{3} \text { Grouth }_{i, t}+\beta_{4} \text { Equity }_{i, t}+\alpha_{0}+\varepsilon_{i, t}
$$

Build model (2) to test the relationship of three sub dimensions of financing ecological environment (E1, E2, E3) and enterprises' $R \& D$ investment:

$$
R D_{i, t}=\beta_{1} E 1_{i, t}+\beta_{2} E 2_{i, t}+\beta_{3} E 3_{i, t}+\beta_{4} \text { LnAsset }_{i, t}+\beta_{5} \text { Grouth }_{i, t}+\beta_{6} \text { Equity }_{i, t}+\alpha_{0}+\varepsilon_{i, t}
$$

\subsubsection{Test Hypothesis $\mathrm{H} 2$}

Build model (3) to test the relationship of new metrial enterprises' financing capacity and R\&D investment:

$$
R D_{i, t}=\beta_{1} R Z_{i, t}+\beta_{2} \text { LnAsset }_{i, t}+\beta_{3} \text { Grouth }_{i, t}+\beta_{4} \text { Equity }_{i, t}+\alpha_{0}+\varepsilon_{i, t}
$$

\subsubsection{Test Hypothesis $\mathrm{H} 3$}

In this paper, we used the three-step regression method of Wen and Ye (2014) to test the mediating effect.

Build model (4) and (5), with (1) to test the relationship of financing ecological environment, enterprises' financing capacity and $\mathrm{R} \& \mathrm{D}$ investment:

$$
\begin{gathered}
R Z_{i, t}=\beta_{1} E_{i, t}+\beta_{2} \text { LnAsset }_{i, t}+\beta_{3} \text { Grouth }_{i, t}+\beta_{4} \text { Equity }_{i, t}+\alpha_{0}+\varepsilon_{i, t} \\
R D_{i, t}=\beta_{1} E_{i, t}+\beta_{2} R Z_{i, t}+\beta_{3} \text { LnAsset }_{i, t}+\beta_{4} \text { Grouth }_{i, t}+\beta_{5} \text { Equity }_{i, t}+\alpha_{0}+\varepsilon_{i, t}
\end{gathered}
$$

Build model (6) and (7), with (2) to test the relationship of three sub dimensions of financing ecological environment (E1, E2, E3), enterprises' financing capacity and R\&D investment:

$$
\begin{gathered}
R Z_{i, t}=\beta_{1} E 1_{i, t}+\beta_{2} E 2_{i, t}+\beta_{3} E 3_{i, t}+\beta_{4} \text { LnAsset }_{i, t}+\beta_{5} \text { Grouth }_{i, t}+\beta_{6} \text { Equity }_{i, t}+\alpha_{0}+\varepsilon_{i, t} \\
R D_{i, t}=\beta_{1} E 1_{i, t}+\beta_{2} E 2_{i, t}+\beta_{3} E 3_{i, t}+\beta_{4} R Z_{i, t}+\beta_{5} \text { LnAsset }_{i, t}+\beta_{6} \text { Grouth }_{i, t}+\beta_{7} \text { Equity }_{i, t}+\alpha_{0}+\varepsilon_{i, t}
\end{gathered}
$$

\subsection{Sample Selection}

The initial sample is A-share market of Shanghai and Shenzhen in 2010-2015, through the following screening: (1) selecting listed companies whose new material business income accounts for more than $50 \%$ of all business income, or whose new material business income and profits are the highest in all business income and profits and account for more than $30 \%$ of all business income and profits; (2) eliminating listed companies those are ST, *ST, and PT from 2010 to 2015; (3) removing the companies who lost financial data between 2010 and 2015. Eventually, we get 203 new material listed companies for 2010-2015 years as research samples.

\section{Empirical Results and Analysis}

\subsection{Unit Root Test}

\begin{tabular}{|c|c|c|c|c|c|c|c|c|}
\hline \multirow{2}{*}{ Variables } & \multicolumn{4}{|c|}{ Original test results } & \multicolumn{4}{|c|}{ First order difference test results } \\
\hline & LLC & IPS & ADF-Fisher & PP-Fisher & LLC & IPS & ADF-Fisher & PP-Fisher \\
\hline $\mathrm{RD}$ & $-133.56^{* * * *}$ & $-5.78 * * *$ & $694.31 * * *$ & $1171.83^{* * * *}$ & $-833.92 * * *$ & $-128.83 * * *$ & $1027.40^{* * * *}$ & $1619.36 * * *$ \\
\hline E1 & $-65.99 * * *$ & $-4.65 * * *$ & $725.31 * * *$ & $1404.46^{* * * *}$ & $-38.94 * * *$ & $-11.73^{* * *} *$ & $756.58 * * *$ & $1343.71 * * *$ \\
\hline E2 & $-24.12 * * *$ & 2.63 & 249.51 & 405.53 & $-43.68 * * *$ & $-1.51 * *$ & $380.23 * *$ & $677.23 * * *$ \\
\hline E3 & $-44.45 * * *$ & $-1.85^{* *}$ & $547.51 * * *$ & $1070.08 * * *$ & $-69.63 * * *$ & $-10.88 * * *$ & $750.40 * * *$ & $1144.51 * * *$ \\
\hline $\mathrm{E}$ & $-123.71 * * *$ & $-6.08 * * *$ & $659.53^{* * *}$ & $1030.68 * * *$ & $-72.98 * * *$ & $-11.40^{* * *}$ & $747.35^{* * *}$ & $1337.91 * * *$ \\
\hline $\mathrm{RZ}$ & $-50.69 * * *$ & $-2.57 * *$ & $579.76^{* * *} *$ & $1012.53 * * *$ & $-85.13 * * *$ & $-13.55^{* * *} *$ & $685.81 * * *$ & $1119.30 * * *$ \\
\hline Size & $-129.54 * * *$ & $-5.34 * * *$ & $543.78 * * *$ & $910.51 * * *$ & $-278.14 * * *$ & $-125.62 * * *$ & $723.73 * * *$ & $1085.16^{* * *}$ \\
\hline Growth & $-51.30 * * *$ & -1.02 & $486.33 * * *$ & $884.04 * * *$ & $-61.66^{* * *}$ & $-10.49 * * *$ & $624.86^{* * *}$ & $995.33 * * *$ \\
\hline Equity & $-29.22 * * *$ & 0.01 & 411.57 & $689.35^{* * *}$ & $-153.09 * * *$ & $-16.55^{* * *}$ & $534.65^{* * *}$ & $819.20 * * *$ \\
\hline
\end{tabular}

To prevent spurious regression, the stationarity test of data should be carried out first. The methods, LLC, IPS, ADF-Fisher and PP-Fisher have been used to do the unit root test. According to Table 4, we have found that "E2", "Growth" and "Equity" accept the null hypothesis in some methods, namely the unit root exists. Therefore the original series is unstable. By first order differential processing, all sequences are stable, which are first-order stationary single integral sequences.

Table 4. Result of unit root tests

Note. $*$ implies test is significant at $10 \%$ confidence levels, $* *$ implies test is significant at $5 \%$ confidence levels, $* * *$ implies test is significant at $1 \%$ confidence levels. 


\subsection{Cointegration Test}

To investigate whether there is a long-run equilibrium relationship between first-order stationary single sequences, we conduct cointegration tests (Kao test). Table 5 shows that the results have rejected the null hypothesis at a significant level of 5\%, which means that there is a long-term stable relationship between new material enterprises' $R \& D$ investment, financing ecological environment, financing capacity and controlled variables. Therefore, We can use panel data for regression analysis.

Table 5. Result of cointegration test

\begin{tabular}{|c|c|c|c|}
\hline Variables & Null hypothesis & Statistic name & Value-T (Prob.) \\
\hline RD, RZ, Size, Growth, Equity & No Cointegration & $\mathrm{ADF}$ & $-3.359(0.0004)$ \\
\hline RD, E, Size, Growth, Equity & No Cointegration & $\mathrm{ADF}$ & $-2.600(0.0047)$ \\
\hline RZ, E, Size, Growth, Equity & No Cointegration & $\mathrm{ADF}$ & $-5.905(0.0000)$ \\
\hline RD, E, RZ, Size, Growth, Equity & No Cointegration & $\mathrm{ADF}$ & $-2.726(0.0032)$ \\
\hline RD, E1, E2, E3, Size, Growth, Equity & No Cointegration & $\mathrm{ADF}$ & $-2.116(0.0172)$ \\
\hline RZ, E1, E2, E3, Size, Growth, Equity & No Cointegration & $\mathrm{ADF}$ & $-5.896(0.0000)$ \\
\hline RD, E1, E2, E3, RZ, Size, Growth, Equity & No Cointegration & $\mathrm{ADF}$ & $-2.183(0.0145)$ \\
\hline
\end{tabular}

\subsection{Regression Result Analysis}

To select the most effective econometric model, we test the validity of the individual fixed effects model and the mixed effects model by F test, and test the validity of the fixed effects model and the random effects model by Hausman test. According to table 6, the random effects model is the most suitable model and adopted in this paper.

Table 6. the Best model of panel data

\begin{tabular}{cccc}
\hline & F-test & \multicolumn{2}{c}{ Hausman test } \\
Value-F & Critical value & Chi-Sq. Statistic & Prob. \\
\hline 4.81 & 3.7 & 17.314952 & 0.7436 \\
\hline reject the null hypothesis & accept the null hypothesis & random effects model \\
\hline
\end{tabular}

\subsubsection{Financing Ecological Environment and Enterprises’ R\&D Investment}

The empirical result of model (1) in Table 7 shows that, financing ecological environment has a significant positive correlation with $R \& D$ investment, which means the overall improvement of financing ecological environment will promote R\&D investment of new material enterprises. In other words, the hypothesis $\mathrm{H} 1$ has been verified. However, in the model (2), the regression coefficient of system and honesty is negative at $5 \%$ confidence levels. The reason might be that the standardized administration and law enforcement will strictly verify enterprises' $R \& D$ projects, which may slow down the speed of R\&D subsidy funds. What's more, the standardization of system and honesty may also lead to the increasing cost of credit maintenance, and further discourage their enthusiasm of R\&D investment.Furukawa (2010) pointed out that the relationship of intellectual property protection in the institutional environment and the technological innovation shows a nonlinear relation of "inverted U". And the continuous perfection of the intellectual property protection system will suppress the initiative of technological innovation. Referring to this point of view, in the short term, China's institutional environment has played a negative role in enterprise R\&D investment. After a certain point, it will have a positive effect. The regression coefficients of economic development and financial development are respectively positive at $1 \%$ and $5 \%$ confidence levels. It shows that the positive impact of economic development and financial development on R\&D investment of new material enterprises is far greater than the negative impact of system and honesty, which is the reason why the impact of financing ecological environment on R\&D investment is positive in the model (1).

\subsubsection{Enterprises' Financing Capacity and R\&D Investment}

The test of model (3) shows that, the financing capacity of new material enterprises has a significant positive correlation with $R \& D$ investment, which indicates that the raise of financing capacity can motivate the enthusiasm of R\&D investment. Therefore, the hypothesis $\mathrm{H} 2$ has been verified.

\subsubsection{Financing Ecological Environment, Enterprises’ Financing Capacity and R\&D Investment}

The test of mediating effect takes three regressions. The first step is to study the relationship between 
independent variable and dependent variable by testing whether the regression coefficient of independent variable is significant in model (1) and (2). The second step is to study the relationship between independent variable and mediating variable by testing whether the regression coefficient of independent variable is significant in model (4) and (6). The third step is to study the relationship between the three, independent variables, mediating variables and dependent variables, by testing whether the regression coefficients of independent variable and mediating variable are significant in model (5) and (7). If the three steps all pass the significance test, the mediating effect does exist.

The first step has been done in the previous context (see 4.3.1), and the regression coefficients of independent variables are significant. The result of the second step shows that the regression coefficient of financing ecological environment is positive at $1 \%$ confidence levels in the model (4), and the regression coefficients of economic development and financial development are positive at 5\% confidence levels in the model (6). Distinctively, the regression coefficient of system and honesty is negative at $10 \%$ confidence levels in the model (6), which shows that the perfection of judicial system and the strict management of government regulate the financing channels, and block enterprises' illegal financing channels. Though system and honesty have a negative influence on R\&D investment in the short term, but it will be positive with the development of institutional level in the long run. Liao and Chen (2011) also noted in their research that the negative impact of government regulation and intervention is bigger than the positive effect of government services, since China is in the period of economic transition. Therefore, compared with the market leading resource allocation, enterprises will have less space and channels to obtain funds, which will negatively affect the enterprise's R\&D investment. The third step has been done and indicates that the regression coefficients of financing ecological environment and financing capacity are positive at $1 \%$ confidence levels in the model (5), and the positive significance of economic development and financial development are greater than the negative significance of system and honesty in model (7). In summary, the results of the tests show that the hypothesis $\mathrm{H} 3$ has been verified. In other words, financing capacity does play an intermediary role in financing ecological environment and $R \& D$ investment.

In addition, referring to the research of Wen Z. L. (2014), the total effect of financing ecological environment on R\&D investment of new material enterprises is 0.0137 by the testing result of model (1), and the mediating effect of financing capacity is $0.0032(0.0653 \times 0.0492)$, the direct effect is 0.0105 , which means the intermediary effect of the financing capacity is $23.42(0.0032 / 0.0137)$ percentage of the total effect, and $30.58(0.0032 / 0.0105)$ percentage of the direct effect.

Table 7. Regression results of random-effect panel model

\begin{tabular}{|c|c|c|c|c|c|c|c|}
\hline Variables & $\begin{array}{l}\text { Model (1) } \\
\text { coefficient }\end{array}$ & $\begin{array}{l}\text { Model (2) } \\
\text { coefficient }\end{array}$ & $\begin{array}{l}\text { Model (3) } \\
\text { coefficient }\end{array}$ & $\begin{array}{l}\text { Model (4) } \\
\text { coefficient }\end{array}$ & $\begin{array}{l}\text { Model (5) } \\
\text { coefficient }\end{array}$ & $\begin{array}{l}\text { Model (6) } \\
\text { coefficient }\end{array}$ & $\begin{array}{l}\text { Model (7) } \\
\text { coefficient }\end{array}$ \\
\hline E1 & & $\begin{array}{c}0.0185 * * * \\
4.85\end{array}$ & & & & $\begin{array}{c}0.0534 * * \\
3.53\end{array}$ & $\begin{array}{c}0.0161 * * * \\
4.73\end{array}$ \\
\hline E2 & & $\begin{array}{c}0.0100 * * \\
3.09\end{array}$ & & & & $\begin{array}{c}0.0251 * * \\
3.79\end{array}$ & $\begin{array}{c}0.0089 * * \\
2.96\end{array}$ \\
\hline E3 & & $\begin{array}{c}-0.0134 * * \\
-3.27\end{array}$ & & & & $\begin{array}{c}-0.0612^{*} \\
-2.39\end{array}$ & $\begin{array}{c}-0.0107 * \\
-1.83\end{array}$ \\
\hline E & $\begin{array}{c}0.0137 * * * \\
3.81\end{array}$ & & & $\begin{array}{c}0.0653 * * * \\
3.57\end{array}$ & $\begin{array}{c}0.0105 * * * \\
7.08\end{array}$ & & \\
\hline $\mathrm{RZ}$ & & & $\begin{array}{c}0.0293^{* * *} \\
3.87\end{array}$ & & $\begin{array}{c}0.0492 * * * \\
3.79\end{array}$ & & $\begin{array}{c}0.0447 * * * \\
4.22\end{array}$ \\
\hline Size & $\begin{array}{c}0.0029 * * * \\
4.05\end{array}$ & $\begin{array}{c}0.0027 * * * \\
4.56\end{array}$ & $\begin{array}{c}0.0028 * * * \\
4.03\end{array}$ & $\begin{array}{c}0.0288 * * * \\
13.89\end{array}$ & $\begin{array}{c}0.0027 * * * * \\
3.91\end{array}$ & $\begin{array}{c}0.0100^{* * * *} \\
3.80\end{array}$ & $\begin{array}{c}0.0025 * * * \\
4.35\end{array}$ \\
\hline Growth & $\begin{array}{c}0.0048 * * * \\
5.04\end{array}$ & $\begin{array}{c}0.0042 * * * \\
4.50\end{array}$ & $\begin{array}{c}0.0044 * * * \\
3.63\end{array}$ & $\begin{array}{c}0.0075 \\
1.13\end{array}$ & $\begin{array}{r}0.0045 * * * \\
4.73\end{array}$ & $\begin{array}{c}0.0180 * * * * \\
5.56\end{array}$ & $\begin{array}{c}0.0039 * * * \\
4.16\end{array}$ \\
\hline Equity & $\begin{array}{c}-0.0112 \text { *** } \\
-3.66\end{array}$ & $\begin{array}{c}-0.0044 \\
-1.31\end{array}$ & $\begin{array}{c}-0.0135 * * * \\
-3.18\end{array}$ & $\begin{array}{c}0.0979 * * * * \\
6.87\end{array}$ & $\begin{array}{c}-0.0129 * * * \\
-3.05\end{array}$ & $\begin{array}{c}0.0988 * * * * \\
6.74\end{array}$ & $\begin{array}{c}-0.0063 * \\
-1.86\end{array}$ \\
\hline Intercept & $\begin{array}{c}0.0731 * * * \\
6.26\end{array}$ & $\begin{array}{c}0.0669 * * * \\
6.56\end{array}$ & $\begin{array}{c}0.0682 * * * \\
5.59\end{array}$ & $\begin{array}{c}0.9445 \text { *** } \\
27.79\end{array}$ & $\begin{array}{c}0.0613 * * * \\
4.95\end{array}$ & $\begin{array}{c}0.6837 * * * * \\
14.94\end{array}$ & $\begin{array}{c}0.0558 * * * \\
5.22\end{array}$ \\
\hline $\mathrm{R}^{2}$ (overall) & 0.487 & 0.599 & 0.494 & 0.427 & 0.673 & 0.549 & 0.759 \\
\hline Value-Wald & $116.43^{* * *}$ & $142.93^{* * * *}$ & $127.19 * * *$ & $128.61 * * *$ & $187.63^{* * *}$ & $142.87 * * *$ & $238.45^{* * * *}$ \\
\hline
\end{tabular}

Note. * implies test is significant at $10 \%$ confidence levels, $* *$ implies test is significant at $5 \%$ confidence levels, $* * *$ implies test is significant at $1 \%$ confidence levels. 


\subsubsection{Robustness Test}

To ensure the reliability of the conclusion, the following robustness tests are carried out: (1) All the continuous variables have been processed by Winsorize at the level of $1 \%$, and then the regression of random-effect panel data have been performed, whose results are basically consistent. (2) The processing method of the two sub dimensions (economic development and financial development) of financing ecological environment have been changed into principal component analysis method, whose conclusions are also basically consistent.

\section{Conclusions and Recommendations}

\subsection{Conclusions}

On one side, financing ecological environment has a significant impact on R\&D investment of new material enterprises, in which sub dimensions economic development and financial development play a positive role, while system and integrity play a negative role. The improvement of financing capacity can promote R\&D investment. The financing ecological environment promotes new material enterprises' R\&D investment activities through the transmission of financing capability. In other words, there are different interaction and influence effects between financing ecological environment, new material enterprises' financing capability and R\&D investment. As can be seen from the model (2), (6) and (7), the sub dimension of economic development has the greatest impact on the financing capacity and R\&D investment, indicating that regional economic development is an important prerequisite for improving financing ecological environment and promoting enterprises' $R \& D$ investment.

On the other side, financing ecological environment has two significant effects on promoting R\&D investment activities of new material enterprises. First is the direct effect. The improvement of financing ecological environment can promote new material enterprises' R\&D investment. Second is the indirect effect. Financing ecological environment can promote $R \& D$ investment activities through enhancing financing capacity, among which, the intermediary effect of financing capacity accounts for $23.42 \%$ of the total effect and accounts for $30.58 \%$ of the direct effect. In other words, improving the financing ecological environment of new materials enterprises can strengthen their financing capacity, thus raising more external funds to support R\&D investment.

\subsection{Recommendations}

Combining the idea of coevolution of ecosystem, new material enterprises should make full use of regional economic development and resource abundance differences to conduct management, and thoroughly consider the influence of regional financing ecology constraints on the fund allocation. Based on the scientific analysis of ecological integration of new material enterprises' financing capacity, fund supply and demand and the efficiency of fund allocation, China's government should give full play to the synergy of economic, financial, fiscal and industrial policies to promote the development of new material industry, and help promote the resource integration among regional financial institutions, intermediary organizations and new material enterprises to develop new material technologies with regional characteristics, such as rare earth materials in Inner Mongolia and nonferrous metals in Guangxi. Besides, the government should pay attention to optimizing social economy and financing ecological environment, encouraging financial products and services, establishing and standardizing the multi-level capital market system, and properly guiding the flow of capital to high-tech innovation areas. What's more, government departments need to improve work efficiency, enhance credibility, and perfect the credit information system to enhance social credit transparency and support intermediary services such as accounting, auditing, legal services and asset evaluation, etc.

What's more, China's new material enterprises should continually promote adaptive coordination of R\&D fund allocation and financing ecology. Relying on the advantages of regional resources and industrial alliances, new material enterprises should cooperate with universities and scientific research institutions to improve R\&D conversion rate, which can lower the financing threshold and attract more investment opportunities. Most important of all, the urgency for new material enterprises is to quickly adapt and integrate into the complex financing ecological environment, and take full use of stock market, trusts, credit guarantees and other forms of financing to expand financing options. By these ways, China's new material enterprises can get out of the predicament of relying on internal funds and bank credit, enhance R\&D capital allocative efficiency, and create high-quality capital power engine.

\section{Acknowledgments}

The topic originates from China Social Science Fund "Research on financing ecology, financing efficiency and co evolution mechanism of strategic emerging industries in China" (project approval No. 15BGL056), Philosophy and Social Science Project in Jiangsu Province "Research on the efficiency of capital allocation and 
its synergetic evolution mechanism of strategic emerging industries in Jiangsu under new normal conditions" (project approval No. 2015ZDIXM008), and Central University Research Project Raising Fund "Study on financing ecology, financing efficiency and financial support system of strategic emerging industries in China" (item No. NP2015302).

The author would like to thank Professor Geng from Nanjing University of Aeronautics and Astronautics, the editor and anonymous reviewers for their professional comments.

\section{References}

Ali, G., Gönül, Ç., \& Özde, Ö. (2017). Political environment, financial intermediation costs, and financing patterns. Journal of Corporate Finance, (44), 167-192.

Cao, Q. G., Ren, G. L., \& Luo, Y. L. (2014). The impact of regional institutional environment on enterprises' technological innovation. Finance and Economics Science, (1), 71-80.

Chen, X. H., Wang, Y., \& Guan, Y. J. (2012). Financial redundancy, institutional environment and R\&D investment of small and medium sized Enterprises. Science Research, 1537-1545.

Dai, X. Y., \& Cheng, L. W. (2015). The impact of financial development on corporate financing constraints and R\&D investment. Research and Development Management, (3), 25-33.

Fernanda, C., Aquiles, E. G. K., \& Carlos, M. (2015). Financing in an emerging economy: Does financial development or financial structure matter? Emerging Markets Review, (6), 96-123.

Furukawa, Y. (2010). Intellectual property protection and innovation: An inverted-U relationship. Economics Letters, 109(2), 99-101. https://doi.org/10.1016/j.econlet.2010.09.004

Hiroyuki, K., Katsumi, S., \& Michio, S. (2014). Does an R\&D tax credit affect R\&D expenditure? The Japanese $\mathrm{R} \& \mathrm{D}$ tax credit reform in 2003. Journal of the Japanese and International Economies, 31, 72-97. https://doi.org/10.1016/j.jjie.2013.10.005

Huang, M. Y. (2015). Research on regional financial development based on Bayes spatial econometric model (Master's thesis, Jinan University, Guangdong, China).

James, R. B., Gustav, M., \& Bruce, C. P. (2012). Do financing constraints matter for R\&D? . European Economic Review, 56(8), 1512-1529. https://doi.org/10.1016/j.euroecorev.2012.07.007

Li, M. M., Xiao, H. J., \& Zhao, S. (2015). A study on the relationship between financial development, technological innovation and economic growth -- Based on the panel data of China's provinces. China Management Science, (2), 162-169.

Li, X. J., \& Fang, B. (2014). Study on Regionalization of urbanization quality in economically developed areas based on Catastrophe Theory - A case study of 13 cities in Jiangsu Province. Economic Geography, (3), 65-71.

Liao, K. R., \& Chen, S. Y. (2011). An empirical study on the impact of institutional environment on R\&D investment of private enterprises. Science Research, (9), 1342-1348.

Liu, Y. C. (2014). R\&D investment, financing constraints and dependence on external financing: An empirical study based on listed companies. Scientific and Technological Progress and Countermeasures, (4), 20-25.

Lu, L. J., \& Zheng, X. B. (2007). Research on the correlation between regional economic development difference and innovation network connectivity: Based on questionnaire survey and field interview of R\&D center of 83 enterprises in Zhejiang. Science and Management of Science and Technology, (10), 130-134.

Marianna, M., Stephane, L., Pierpaolo, P., \& Davide, S. (2016). Additionality or crowding-out? An overall evaluation of public R\&D subsidy on private R\&D expenditure. Research Policy, (9), 1715-1730. https://doi.org/10.1016/j.respol.2016.04.009

Oliviero A. C. (2017). The effect of public support on investment and R\&D: An empirical evaluation on European manufacturing firms. Technological Forecasting and Social Change, 117, 282-295. https://doi.org/10.1016/j.techfore.2016.11.017

Pasi, K. (2008). R\&D investments: The effects of different financial environments on firm profitability. Journal of Multinational Financial Management, 18(2), 79-93. https://doi.org/10.1016/j.mulfin.2007.02.006

Qian, J., \& Strahan, P. E. (2007). How laws and institutions shape financial contracts: The case of bank loans. The Journal of Finance, 62(6), 2803-2834. https://doi.org/10.1111/j.1540-6261.2007.01293.x 
Song, M. L., Ai, H. S., \& Li, X. (2015). Political connections, financing constraints, and the optimization of innovation efficiency among China's private enterprises. Technological Forecasting and Social Change, (3), 290-299. https://doi.org/10.1016/j.techfore.2014.10.003

Subash S., P. J. Jijo L., \& Surenderrao, K. (2015). Financing constraints and investments in R\&D: Evidence from Indian manufacturing firms. The Quarterly Review of Economics and Finance, 55, 28-39. https://doi.org/10.1016/j.qref.2014.07.002

Tan, X. F., \& Fan, J. (2016). Research on the influence of the combination of industry and finance on the financing ability of agricultural listed companies. Agricultural Economics, (06), 50-60.

Wang, H., Liang, P., Li, H. Y., \& Yang, R. L. (2016). Financing Sources, R\&D Investment and Enterprise Risk. Procedia Computer Science, 91, 122-130. https://doi.org/10.1016/j.procs.2016.07.049

Wang, L. Y. (2016). The influence of financial development on R\&D investment intensity of GEM Enterprises (Zhejiang Industry and Commerce University, Zhejiang, China).

Wang, M., Yang, Y. G., \& Yang, H. P. (2011). Research on comprehensive evaluation index system of economic development level of Urban Agglomeration - Taking Central Plains as an example. Surveying and Mapping Science, (6), 64-66.

Wei, Z. H., Wang, Z. J., Wu, Y. H., \& Li, C. Q. (2012). Financial ecological environment, audit opinions and debt financing costs. Audit Research, (3), 98-105.

Wen, Z. L., Ye, B. J. (2014). Mediating effect analysis: Methods and models development. Advances in Psychological Science, 22(5), 731-74. https://doi.org/10.3724/SP.J.1042.2014.00731

Yu, F. F., Guo, Y., Khuong, L., Stuart, J. B., \& Zhang, W. T. (2016). The impact of government subsidies and enterprises' R\&D investment: A panel data study from renewable energy in China. Energy Policy, 89, 106-113. https://doi.org/10.1016/j.enpol.2015.11.009

Zhai, S. P., \& Gu, Q. (2013). Financial development, mitigation of financing constraints and efficiency of R\&D investment of high tech enterprises. Economic Journal, (2), 138-143.

Zheng, S. Z., \& Huang, M. Y. (2015). Analysis of influencing factors of regional financial development based on Bayes spatial model. Business Research, (01), 62-69.

Zheng, Y. Y., Dai, X. H., \& Wei, Q. (2017). Financing constraints and enterprise R\&D investment data: Based on Chinese industrial enterprises. Journal of Central University of Finance and Economics, (5), 58-66.

Zong, G., \& Gao, Y. (2017). The study of regional economic growth and endogenous technological innovation -Based on the analysis of China provincial panel data of 2003-2014. Journal of Hebei University of Economics and Business, (2), 101-105.

\section{Copyrights}

Copyright for this article is retained by the author(s), with first publication rights granted to the journal.

This is an open-access article distributed under the terms and conditions of the Creative Commons Attribution license (http://creativecommons.org/licenses/by/4.0/). 